\title{
PERBEDAAN PENGARUH FREKUENSI LATIHAN SENAM AEROBIK TERHADAP PENURUNAN PERSENTASE LEMAK TUBUH DAN BERAT BADAN PADA MEMBERS WANITA
}

Oleh

Azmy Andini dan Eka Novita Indra

Elfiannisa Jurusan Pendidikan Kesehatan dan Rekreasi FIK UNY

\section{Abstrak}

Senam aerobik merupakan salah satu jenis latihan fisik yang digunakan sebagai sarana mencegah dan menurunkan berat badan serta sebagai sarana rehabilitasi atau terapi yang efektif. Penelitian ini bertujuan untuk mengetahui perbedaan pengaruh frekuensi latihan senam aerobik terhadap penurunan persentase lemak tubuh dan berat badan pada members wanita di Cakra Sport Club Yogyakarta.

Penelitian ini merupakan penelitian eksperimen dengan desain penelitian two group pretest-posttest. Subjek dalam penelitian ini adalah member wanita senam aerobik yang aktif di Cakra Sport Club Yogyakarta yang berjumlah 14 orang. Instrumen untuk mengukur lemak tubuh dan berat badan menggunakan alat elektrik dengan sistem digital yaitu Omron Body Composition Monitor, pengukuran dilakukan dengan cara memasukkan data tinggi badan, usia dan jenis kelamin. Teknik analisis data menggunakan uji normalitas dengan uji Kolmogorov-Smirnov Z, uji homogenitas dengan uji Bartllet dan pengujian hipotesis yang menggunakan analisis data kuantitatif dengan uji-t.

Hasil analisis penelitian ini menunjukkan uji-t terhadap penurunan persentase lemak tubuh, menghasilkan $t_{\text {hitung }}$ sebesar 2,509\% dengan $\mathrm{p}<0,05$ (signifikan). Rata-rata penurunan persentase lemak tubuh pada subjek penelitian dengan frekuensi latihan $\geq 3$ kali adalah 2,386 \%, nilai tersebut lebih tinggi dibandingkan dengan rata-rata penurunan persentase lemak tubuh pada subjek penelitian dengan frekuensi latihan $\leq 2$ kali yang hanya sebesar $0,829 \%$. Hasil analisis uji-t terhadap berat badan, menghasilkan $t_{\text {hitung }}$ sebesar 2,650 kg dengan $\mathrm{p}<0,05$ (signifikan). Rata-rata penurunan berat badan pada subjek penelitian dengan frekuensi senam aerobik latihan $\geq 3$ kali adalah $3,371 \mathrm{~kg}$, nilai tersebut lebih tinggi dibandingkan dengan rata-rata penurunan berat badan pada subjek penelitian dengan frekuensi latihan $\leq 2$ kali sebesar $1,443 \mathrm{~kg}$. Berdasarkan hasil penelitian dapat disimpulkan bahwa frekuensi senam aerobik $\geq 3$ kali dalam seminggu dapat menurunkan persentase lemak tubuh dan berat badan lebih tinggi daripada frekuensi senam aerobik $\leq 2$ kali dalam seminggu.

Kata Kunci: Senam Aerobik, Frekuensi Latihan, Persentase Lemak Tubuh, Berat Badan

Hidup sehat dengan berat badan ideal adalah dambaan setiap wanita. Namun pada kenyataannya tidak semua wanita memiliki berat badan yang ideal. Kebiasaan konsumsi makanan siap saji dan makanan dengan gizi yang tidak seimbang membuat tubuh menyimpan banyak kalori. Jarangnya bergerak, sedikit beraktivitas dan jarangnya berolahraga membuat metabolisme tubuh menjadi berkurang, lemak yang terbakar untuk menghasilkan energi 
menjadi sedikit sehingga terjadinya penimbunan lemak yang berlebih ditubuh dan menyebabkan kegemukan atau obesitas. Orang yang memiliki berat badan yang berlebih atau kegemukan memiliki resiko besar terhadap serangan berbagai penyakit degeneratif, seperti: tekanan darah tinggi, penyakit pembuluh darah otak, jantung koroner, diabetes, penyakit sendi dan lain sebagainya.

Umumnya wanita beranggapan bahwa tubuh yang ideal identik dengan tubuh yang kurus dan langsing. Hal itu dikarenakan selain untuk kesehatan bentuk tubuh dan berat badan seringkali juga mempengaruhi penampilan seseorang. Minat terhadap penampilan sangat kuat pada wanita dewasa umumnya. Diet merupakan salah satu cara yang seringkali digunakan para wanita dalam penampilannya. Diet merupakan pengaturan pola makan, baik porsi, maupun kandungan gizinya. Selama diet dilakukan dengan proporsional dengan memperhatikan kebutuhan tubuh, diet akan membentuk tubuh ideal dan tubuh tetap sehat. Akan tetapi jika dilakukan dengan sembarangan, diet dapat berakibat fatal.

Sekarang ini kesadaran wanita akan hidup sehat melalui olahraga semakin meningkat. Hal ini dapat dilihat dari tempat pusat-pusat kebugaran terutama klub-klub senam semakin banyak. Salah satu jenis latihan fisik yang sangat diminati dan digunakan untuk meningkatkan kebugaran fisik oleh kaum wanita adalah senam aerobik. Senam aerobik merupakan salah satu jenis latihan fisik yang digunakan sebagai sarana mencegah dan menurunkan berat badan serta sebagai sarana rehabilitasi atau terapi yang efektif. Memang banyak manfaat yang dapat diperoleh dari aktivitas ini, mulai dari meningkatkan kerja jantung, meningkatkan kekuatan otot, membakar lemak, serta manfaat-manfaat lainnya bagi tubuh. Kenyataan menunjukkan bahwa belum ada data secara empirik yang melaporkan tentang perubahan-perubahan yang terjadi akibat perbedaan perngaruh frekuensi latihan senam aerobik selama dua bulan khususnya tentang perubahan terhadap berat badan dan persentase lemak tubuhnya di Cakra Sport Club Yogyakarta. Oleh karena itu, perlu didapatkan data empirik mengenai perbedaan pengaruh frekuensi latihan senam aerobik terhadap penurunan berat badan dan persentase lemak tubuh members wanita setelah latihan senam aerobik selama dua bulan di Cakra Sport Club Yogyakarta.

\section{KAJIAN PUSTAKA}

\section{Senam Aerobik}

Menurut Lyne Brick yang dikutip oleh Fajar Sriwahyuniati (2009: 10) tentang senam aerobik menyatakan bahwa:

Senam Aerobik adalah suatu bentuk latihan yang terdiri dari latihan aerobik berirama dengan pelatihan kekuatan dan peregangan yang rutin dalam rangka 
meningkatkan semua unsur-unsur kebugaran (fleksibilitas, kekuatan otot, dan kebugaran cardiovascular). Senam aerobik ini merupakan suatu bentuk proses kegiatan fisik yang ritmis dilakukan secara terus menerus dengan memadukan beberapa gerakan yang bertujuan untuk menguatkan jantung, peredaran darah, otot dan membakar lemak sehingga tubuh memerlukan oksigen yang lebih banyak dan denyut nadi meningkat.

Menurut Brian J. Sharkey (2003) dalam pelaksanaan senam aerobik harus berpedoman kepada dosis latihan yang disesuaikan dengan tujuan latihan. Dosis latihan selalu terkait dengan intensitas, repetisi, frekuensi, dan durasi latihan. Intensitas latihan diartikan sebagai besarnya beban yang harus dilakukan selama latihan dengan indikator peningkatan denyut jantung tiap menitnya atau disebut heart rate latihan. Untuk meningkatkan daya tahan aerobik cukup melakukan latihan selama 30-60 menit secara kontinyu. Pendapat lain mengatakan bahwa latihan aerobik yang dilakukan selama 8-12 minggu secara terus menerus telah memberi efek yang cukup berarti bagi perubahan faal tubuh. Senam aerobik sebagai salah satu bentuk senam yang kompleks, gerakan yang dilakukan memerlukan koordinasi yang cukup dari bagian-bagian tubuh, baik dari kepala sampai kaki. Senam aerobik mudah dilakukan, dapat diikuti oleh siapa saja, remaja, dewasa, yang tua baik laki-laki maupun perempuan.

Menurut Fajar Sriwahyuniati (2009: 10) senam aerobik dilakukan dengan beberapa gerakan yang harus diperhatikan, yaitu gerakan dasar (basic step) yang terdiri dari:

1. Gerakan kaki: gerakan kaki merupakan gerakan dasar yang penting dan harus diperhatikan, sebelum dilanjutkan dengan gerakan tangan. Contoh gerakan dasar kaki: marching in place, step, lunges, V-step, knee up dll.

2. Gerakan lengan: merupakan rangkaian gerakan koordinasi dengan kaki, dengan tujuan agar seluruh komponen tubuh dapat bergerak dengan aktif secara maksimal, contoh gerakan: chest press, overhead, biceps curl, triceps, butter fly dll.

Keberhasilan sebuah program latihan sangat ditentukan oleh kualitas latihan yang salah satunya adalah takaran latihan yang menurut Djoko Pekik (2000: 13) dijabarkan pada konsep FITT (Frequency, Intensity, Time and Type):

1. Frekuensi. Banyaknya unit latihan persatuan waktu, untuk mencapai capaian kebugaran berupa komposisi tubuh ideal dalam latihan memerlukan latihan 3-5 kali per minggu dimana sebaiknya latihan dilakukan berselang karena hari yang lain dipergunakan untuk recovery atau pemulihan.

2. Intensitas. Besarnya intensitas bergantung pada jenis dan tujuan latihan, latihan aerobik menggunakan patokan kenaikan detak jantung (Training Heart Rate $=$ THR). Untuk 
tujuan pembakaran lemak $65 \%-75 \%$ detak jantung maksimal dengan penghitungan detak jantung maksimal yaitu: DJM = 220-Umur.

3. Waktu (time). Waktu atau durasi yang diperlukan setiap kali berlatih untuk meningkatkan kebugaran dan penurunan berat badan diperlukan waktu berlatih 20-60 menit dalam satu sesi latihan.

4. Type, atau jenis latihan. Jenis latihan senam aerobik perlu memperhatikan dasar gerak latihan kebugaran.

Metode latihan aerobik atau komposisi tubuh menurut Djoko Pekik (2000: 56) adalah perbandingan berat badan yang terdiri atas lemak dengan berat badan tanpa lemak. Memiliki ciri-ciri latihan dengan kontinyu, gerak yang dinamis, melibatkan otot-otot besar dan penurunan berat badan yang aman 0,5-1,0 kg/minggu sedangkan jumlah kalori yang dibakar setiap kali latihan kurang lebih 500-1000 kalori.Menurut Suharjana (2013: 66) ditinjau dari berat ringannya latihan senam aerobik terdiri atas gerakan low impact dan high impact:

\section{a) Low Impact}

Latihan low impact adalah latihan yang dilakukan dengan iringan musik dengan irama sedang dengan rangkaian gerakan tanpa menggunakan lompatan-lompatan. Latihan ini cocok untuk pemula dan semua usia.

\section{b) High Impact}

High impact adalah latihan yang dilakukan dengan intensitas yang tinggi diiringi oleh musik yang berirama cepat. Latihan ini cocok bagi peserta yang telah memiliki kualitas dan teknik senam aerobik yang baik. Latihan high impact diikuti dengan lompatanlompatan, dengan tujuan meningkatkan power dan meningkatkan cardiovascular bagi pelakunya. Latihan ini cocok bagi peserta dengan usia 30 tahun atau dibawahnya.

Perpaduan antara low impact dan high impact juga dapat digunakan dalam usaha peningkatan daya tahan aerobik. Senam aerobik jenis ini sering disebut Mix Impact. Biasanya dilakukan secara ritmis dimulai dari low impact kemudian diteruskan dengan high impact. Latihan ini selain untuk meningkatkan daya tahan aerobik, juga dapat meningkatkan power bagi pelakunya. Latihan ini sangat cocok bagi pemula dan yang sudah terlatih.

\section{Berat Badan dan Lemak Tubuh}

1. Berat Badan

Berat badan adalah salah satu parameter yang memberikan gambaran massa tubuh. Kelebihan berat badan timbul karena kalori makanan melebihi kebutuhan tubuh akan 
energi untuk melakukan aktivitas dan metabolisme. Berat badan tidak akan berubah bila menggunakan seluruh makanan untuk bahan bakar dan perbaikan. Tetapi kelebihan kalori akan disimpan sebagai lemak.Ukuran tubuh seseorang biasanya dikaitkan dengan resiko antara, lean body fat (lemak) dengan lean body mass (otot dan tulang), semakin tinggi persentase lemak tubuh, semakin kurang ideal dan memiliki resiko tinggi terhadap serangan berbagai penyakit.

Menurut Djoko Pekik (2000:56) kualitas komposisi tubuh dinyatakan dengan persentase lemak tubuh. Seorang pria dikategorikan bertubuh normal jika memiliki lemak tubuh $15 \%-20 \%$ sedangkan $20 \%-25 \%$. Ukuran tubuh dapat diketahui dengan menggunakan berat badan ideal (BBI).

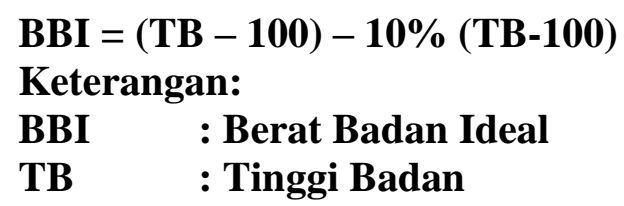

Kelebihan $10 \%$ BBI termasuk kategori berat badan normal (BBN), sedangkan kelebihan diatas $10 \%-25 \%$ untuk pria dan diatas $10 \%$-30\% wanita, termasuk kategori berat badan berlebih (overweight), selebihnya dikategorikan kegemukan (obese). Cara termudah untuk mempertahankan berat badan yang ideal atau bahkan mencapai berat badan yang ideal adalah dengan cara latihan fisik. Efek terbaik dari latihan fisik adalah perubahan komposisi tubuh dan menghasilkan figure yang langsing dan menyenangkan. Aktivitas aerobik merupakan pilihan utama yang banyak ditawarkan oleh pusat-pusat kebugaran sebagai sarana untuk memperoleh berat badan yang ideal. Pada kenyataannya berat badan yang ideal tidak dapat terlepas dari proporsi komponen-komponen badan yang ideal pula, yang dinyatakan dalam persentase terhadap berat badan.

2. Lemak Tubuh

Menurut Djoko Pekik (2006: 10) berdasarkan struktur kimianya, lemak dikelompokkan menjadi beberapa jenis, yang meliputi: simple fat atau lemak sederhana (lemak jenuh dan lemak tak jenuh), lemak ganda (phospolipid, glukolipid, dan lipoprotein), dan lemak tiruan atau derivat lemak (kolesterol). Lemak tidaklah semuanya buruk, lemak merupakan komponen yang penting dari dinding sel, insulin vital dan sistem saraf, pendahulu dari komponen penting seperti hormon, dan penyerap goncangan pada organ dalam. Lemak dapat menjadi bahan bakar yang paling efisien untuk melakukan aktivitas fisik, khususnya pada otot yang lelah menjalani latihan daya tahan. Lemak juga membantu meningkatkan rasa makan. Tersedianya lemak di dalam tubuh ternyata banyak 
manfaatnya, hal ini dapat diketahui dari fungsi-fungsi lemak tersebut. Lemak dalam tubuh bermanfaat sebagai sumber energi, melarutkan vitamin sehingga dapat diserap oleh usus dan memperlama rasa kenyang (Djoko Pekik, 2006: 12).

\section{Latihan Aerobik untuk Membakar Lemak Tubuh}

Menurut Djoko Pekik (2000: 57) latihan untuk menurunkan berat badan atau menurunkan lemak tubuh memiliki ciri-ciri sebagai berikut: gerakannya dinamis yang melibatkan otot-otot besar tubuh, intensitas latihan sedang, dikerjakan secara kontinyu dalam jangka waktu yang cukup lama. Dengan gerakan tersebut sumber energi berasal dari pembakaran lemak. Menurut Brian J. Sharkey (2003: 82) latihan olahraga aerobik dapat meningkatkan fungsi dan kapasitas sistem respiratori dan kardiovaskular serta volume darah, tapi perubahan yang paling penting terjadi pada serat otot yang digunakan dalam latihan. Latihan aerobik meningkatkan kemampuan otot untuk menghasilkan energi secara aerobik dan mengubah metabolisme dari karbohidrat ke lemak. Studi-studi memperhatikan bahwa latihan aerobik yang dilakukan secara teratur, terukur, dan terprogram akan membawa banyak manfaat. Menurut Aine McCarthy (1995: 40) latihan aerobik memberikan pengaruh antara lain sebagai berikut:

a. Latihan aerobik dan penyakit jantung

Latihan aerobik menurunkan kerawanan terhadap penyakit jantung. Latihan aerobik diyakini memainkan suatu peran penting untuk melindungi tubuh dari pengaruhpengaruh aterosklerosis itu.

b. Latihan aerobik dan tekanan darah

Studi-studi memperhatikan bahwa tekanan darah para penderita hipertensi dapat diturunkan ke arah tingkat-tingkat yang wajar dengan latihan aerobik.

c. Latihan aerobik menurunkan kadar lemak tubuh

Penelitian telah dilakukan mengenai hubungan antara lemak tubuh dan kegiatan fisik bahwa latihan aerobik dapat meningkatkan oksidasi lemak tubuh.

d. Latihan aerobik menurunan depresi dan kecemasan

e. Banyak sekali ditemukan kumpulan pengetahuan yang menunjukkan akan pentingnya latihan aerobik dalam penanggulangan penyakit-penyakit mental.

f. Latihan aerobik mengurangi resiko penyakit tulang

Beberapa studi telah membuktikan bahwa latihan aerobik dapat menimbulkan perubahan-perubahan dalam metabolisme tulang yang tampaknya memperlambat kemerosotan yang berlanjut. 
Para pakar menyatakan bahwa, terjadi penyesuaian aerobik yang terjadi pada otototot skeleton, terutama sebagai hasil program latihan endurance atau daya tahan. Menurut Junusul Hairy (1989: 210) yang dikutip oleh Widiyanto (2004: 12) terdapat perubahan-perubahan yang terjadi akibat latihan daya tahan, antara lain sebagai berikut:

a. Perubahan pada komposisi tubuh

Latihan daya tahan dapat mengurangi jumlah lemak tubuh, karena sebagian besar energi yang digunakan dalam latihan daya tahan berasal dari pembakaran lemak tubuh.

b. Perubahan pada tekanan darah

Seseorang yang menderita tekanan darah tinggi kelihatan jelas adanya penurunan tekanan diastole dan sistole pada waktu istirahat.

c. Perubahan pada penyesuaian terhadap panas

Peningkatan aklimatisasi yang disebabkan oleh latihan fisik tampaknya disebabkan oleh sejumlah panas yang dihasilkan selama latihan.

d. Perubahan pada jaringan ikat

Latihan daya tahan akan meningkatkan kekuatan tulang. Sedangkan perubahan pada ligamen-ligamen dan tendon, menjadi lebih kuat dan dalam melekatnya pada tulangpun menjadi lebih kuat.

e. Perubahan pada otot dan serabut-serabut otot

Pengaruh latihan daya tahan terhadap otot, menyebabkan terjadinya peningkatan jumlah serabut di dalam otot.

Beberapa kesalahan yang sering ditemukan adalah orang yang ingin menurunkan berat badan, berlatih sekeras-kerasnya agar banyak mengeluarkan keringat dan membakar energi sebaik-baiknya, atau lama-lama dalam ruang sauna yang dapat mengeluarkan keringat yang banyak dan ditakutkan dapat menyebabkan dehidrasi. Hal tersebut tidak efektif dan merugikan kesehatan, sebab untuk sementara waktu memang berat badan akan turun namun setelah makan dan minum berat badan akan naik kembali, disamping itu pengeluaran keringat yang berlebihan dapat menyebabkan dehidrasi. Menurut Djoko Pekik (2000: 58) penurunan berat badan yang aman 0,5-1,0 Kg/minggu, sedangkan jumlah kalori yang dibakar setiap kali latihan kurang lebih 500-1000 kalori. Akan lebih baik lagi jika program penurunan berat badan disertai dengan program diet. Program latihan fisik yang berfungsi untuk pembakaran lemak tubuh memiliki ciri-ciri antara lain: gerakannya melibatkan otot-otot besar, dilakukan secara kontinyu dengan gerakan ritmis, takaran 
latihan: intensitas $65 \%-75 \%$ detak jantung maksimal, time (durasi) 20-60 menit setiap latihan.

\section{METODE PENELITIAN}

Penelitian ini merupakan penelitian eksperimen dengan desain penelitian two group pretest-posttest. Penelitian ini akan membagi dua kelompok, yaitu kelompok dengan frekuensi latihan senam aerobik $\geq 3$ kali dalam seminggu dan kelompok dengan frekuensi senam aerobik $\leq 2$ kali dalam seminggu. Dalam penelitian ini, peneliti menggunakan data primer, semua pemberian perlakuan dilakukan oleh instruktur di Cakra Sport Club Yogyakarta. Populasi dalam penelitian ini adalah member wanita yang aktif dalam kelas senam aerobik di Cakra Sport Club Yogyakarta sebanyak 57 orang. Jumlah sampel yang memenuhi kriteria dalam penelitian ini adalah 14 orang. Adapun kriteria sampel tersebut adalah : a. Wanita dengan usia produktif, berkisar antara usia 20 - 45 tahun. b. Tidak sedang mengikuti pelatihan fisik yang teratur. c. Sukarela ikut serta dalam penelitian selama dua bulan.

\section{HASIL PENELITIAN DAN PEMBAHASAN}

Pengambilan data pada penelitian ini adalah dengan data primer yang terdiri dari data awal (pre-test) dan data akhir (pos-test). Data pre-test merupakan data sebelum latihan aerobik; sedangkan data post-test adalah data sesudah latihan aerobik selama dua bulan.

\section{Tabel 1. Status Data BBI Pre-test dan Post-test}

\begin{tabular}{|l|l|l|l|l|l|l|l|}
\hline \multirow{2}{*}{ No. } & \multirow{2}{*}{$\begin{array}{c}\text { Tinggi } \\
\text { Badan } \\
(\mathbf{C m})\end{array}$} & $\begin{array}{c}|c| \\
\text { Berat } \\
\text { Badan }(\mathbf{K g})\end{array}$ & $\begin{array}{c}\text { Lemak } \\
\text { Tubuh } \\
(\%)\end{array}$ & BBI & $\begin{array}{c}\text { Perat } \\
\text { Badan } \\
(\mathbf{K g})\end{array}$ & $\begin{array}{c}\text { Lemak } \\
\text { Tubuh } \\
(\%)\end{array}$ & BBI \\
\hline 1 & 162 & 67,4 & 30,4 & Overweight & 64 & 28,1 & Overweight \\
\hline 2 & 146 & 53,7 & 34,6 & Overweight & 49,4 & 28,8 & Normal \\
\hline 3 & 146 & 48,6 & 18,7 & Overweight & 43 & 16,5 & Normal \\
\hline 4 & 155 & 58,1 & 29,3 & Overweight & 57,3 & 29 & Overweight \\
\hline 5 & 150 & 75,9 & 39 & Obese & 73,1 & 38,2 & Obese \\
\hline 6 & 153 & 59,4 & 28,6 & Overweight & 58,4 & 27,6 & Overweight \\
\hline 7 & 155 & 61,6 & 28,5 & Overweight & 59,1 & 27,4 & Overweight \\
\hline 8 & 148 & 58,2 & 34,6 & Obese & 56 & 33,7 & Overweight \\
\hline 9 & 153 & 58,7 & 26,1 & Overweight & 58,6 & 26 & Overweight \\
\hline 10 & 153 & 58,7 & 30,8 & Overweight & 57,3 & 29 & Overweight \\
\hline 11 & 154 & 59,3 & 31 & Overweight & 58,6 & 29,4 & Overweight \\
\hline 12 & 146 & 54 & 26,6 & Obese & 52,9 & 25,6 & Overweight \\
\hline 13 & 146 & 52 & 28,9 & Overweight & 47,7 & 27 & Overweight \\
\hline 14 & 160 & 66,5 & 30,1 & Overweight & 63 & 28,4 & Overweight \\
\hline
\end{tabular}


Deskripsi data tes awal dan data tes akhir persentese lemak tubuh dan berat badan, disajikan pada uraian berikut ini.

1. Persentase Lemak Tubuh

Persentase lemak tubuh diukur dengan Omron Body Composition Monitor, pengukuran dilakukan dengan cara memasukkan data usia, jenis kelamin dan tinggi badan. Data persentase lemak tubuh dilakukan dua kali, yaitu pre-test dan post-test. Setelah data terkumpul, selanjutnya dikoding dan dianalisis, hasil analisis statistik deskriptif presentase lemak tubuh pada sampel penelitian di Pusat Kebugaran Cakra Sport Club Yogyakarta secara ringkas disajikan pada tabel berikut ini.

Tabel 2. Statistik Deskriptif Persentase Lemak Tubuh

\begin{tabular}{|l|l|l|l|l|l|}
\hline \multirow{2}{*}{ No. } & \multirow{2}{*}{ Tendensi Sentral } & \multicolumn{2}{c|}{ Tes Awal } & \multicolumn{2}{c|}{ Tes Akhir } \\
\cline { 3 - 6 } & & $\mathbf{2 3}$ kali & $\mathbf{\leq 2}$ kali & \multicolumn{1}{c|}{$\mathbf{3}$ kali } & \multicolumn{1}{c}{$\mathbf{2}$ kali } \\
\hline 1. & Mean (Rata-rata) & 28,58 & 31,01 & 26,20 & 30,19 \\
\hline 2. & Median & 30,10 & 29,30 & 28,10 & 29,00 \\
\hline 3. & Mode & 18,7 & 26,1 & 16,5 & 26,0 \\
\hline 4. & Standart Deviasi & 4,974 & 4,394 & 4,437 & 6,414 \\
\hline 5. & Varians $\left(\mathrm{SD}^{2}\right)$ & 24,738 & 19,311 & 19,690 & 41,140 \\
\hline 6. & Minimum & 18,7 & 26,1 & 16,5 & 26,0 \\
\hline 7. & Maksimum & 34,6 & 39,0 & 29,0 & 38,2 \\
\hline
\end{tabular}

Tabel tersebut di atas memperlihatkan bahwa persentase lemak tubuh pada members wanita sebagai sampel penelitian dengan frekuensi latihan $\geq 3$ kali; rata-rata tes awal sebesar $28,58 \%$ dan rata-rata tes akhir 26,20 \%. Pada sampel dengan frekuensi latihan $\leq 2$ kali; ratarata tes awal sebesar $31,01 \%$ dan rata-rata tes akhir 30,19\%.

2. Berat Badan

Berat badan dikur dengan menggunakan Omron Body Composition Monitor. Data berat badan ini juga diambil dari data primer. Data berat badan dilakukan dua kali, yaitu pre-test dan post-test. Hasil analisis statistik deskriptif berat badan pada sampel penelitian di Pusat Kebugaran Cakra Sport Club Yogyakarta secara ringkas disajikan pada tabel berikut ini.

Tabel 3. Statistik Deskriptif Berat Badan

\begin{tabular}{|l|l|l|l|l|l|}
\hline \multirow{2}{*}{ No. } & \multirow{2}{*}{ Tendensi Sentral } & \multicolumn{2}{c|}{ Tes Awal } & \multicolumn{2}{c|}{ Tes Akhir } \\
\cline { 3 - 6 } & & $\mathbf{2 3}$ kali & $\mathbf{\leq 2}$ kali & $\mathbf{2} \mathbf{3}$ kali & \multicolumn{1}{c|}{$\mathbf{2}$ kali } \\
\hline 1. & Mean (Rata-rata) & 57,27 & 61,60 & 53,90 & 60,16 \\
\hline 2. & Median & 54,00 & 59,30 & 52,90 & 58,60 \\
\hline 3. & Mode & 48,6 & 58,1 & 43,0 & 58,6 \\
\hline 4. & Standart Deviasi & 7,260 & 6,414 & 7,904 & 5,802 \\
\hline 5. & Varians (SD $\left.{ }^{2}\right)$ & 52,706 & 41,140 & 62,480 & 33,669 \\
\hline 6. & Minimum & 48,6 & 58,1 & 43,0 & 56,0 \\
\hline 7. & Maksimum & 67,4 & 75,9 & 64,0 & 73,1 \\
\hline
\end{tabular}


Tabel tersebut di atas memperlihatkan bahwa berat badan pada members wanita sebagai sampel penelitian dengan frekuensi latihan $\geq 3$ kali; rata-rata tes awal sebesar $57,27 \mathrm{~kg}$ dan rata-rata tes akhir 53,90 kg. Pada sampel dengan frekuensi latihan $\leq 2 \mathrm{kali}$; rata-rata tes awal sebesar $61,60 \mathrm{~kg}$ dan rata-rata tes akhir $60,16 \mathrm{~kg}$.

3. Penurunan Persentase Lemak Tubuh dan Berat Badan

Hasil analisis statistik deskriptif penurunan persentase lemak tubuh dan penurunan berat badan pada members wanita sebagai sampel penelitian di Pusat Kebugaran Cakra Sport Club Yogyakarta secara ringkas disajikan pada tabel berikut ini.

Tabel 4. Statistik Deskriptif Penurunan Persentase Lemak Tubuh dan Berat Badan

\begin{tabular}{|c|c|c|c|c|c|}
\hline \multirow[t]{2}{*}{ No. } & \multirow[t]{2}{*}{ Tendensi Sentral } & \multicolumn{2}{|c|}{$\begin{array}{l}\text { Penurunan \% } \\
\text { Lemak Tubuh }\end{array}$} & \multicolumn{2}{|c|}{$\begin{array}{c}\text { Penurunan Berat } \\
\text { Badan }\end{array}$} \\
\hline & & $\geq 3$ kali & $\leq 2$ kali & $\geq 3$ kali & $\leq 2$ kali \\
\hline 1. & Mean (Rata-rata) & 2,386 & 0,829 & 3,371 & 1,443 \\
\hline 2. & Median & 1,900 & 0,900 & 3,500 & 1,000 \\
\hline 3. & Mode & 1,00 & 0,1 & 4,3 & 0,1 \\
\hline 4. & Standart Deviasi & 1,564 & 0,502 & 1,620 & 1,041 \\
\hline 5. & Varians $\left(\mathrm{SD}^{2}\right)$ & 2,445 & 0,252 & 2,626 & 1,083 \\
\hline 6. & Minimum & 1,0 & 0,1 & 1,1 & 0,1 \\
\hline 7. & Maksimum & 5,8 & 1,6 & 5,6 & 2,8 \\
\hline
\end{tabular}

Tabel tersebut di atas memperlihatkan bahwa rata-rata penurunan persentase lemak tubuh pada kelompok subjek penelitian dengan frekuensi latihan $\geq 3$ kali sebesar 2,386 $\%$; sedangkan pada kelompok subjek penelitian dengan frekuensi latihan $\leq 2$ kali diperoleh rata-rata sebesar 0,829\%. Rata-rata penurunan berat badan pada kelompok subjek penelitian dengan frekuensi latihan $\geq 3$ kali sebesar $3,371 \mathrm{~kg}$; sedangkan pada kelompok subjek penelitian dengan frekuensi latihan $\leq 2$ kali diperoleh rata-rata sebesar $1,443 \mathrm{~kg}$.

\section{PEMBAHASAN}

Penelitian ini membuktikan bahwa terdapat pengaruh yang signifikan antara frekuensi senam aerobik terhadap penurunan persentase lemak tubuh dan berat badan di Cakra Sport Club Yogyakarta. Menurut Prijo Sudibjo (1999: 86) yang dikutip oleh Widiyanto (2004: 59) aktivitas aerobik yang mempunyai pengaruh besar pada lemak tubuh adalah semua bentuk aktivitas aerobik yang dilakukan pada intensitas rendah sampai sedang. Aktivitas aerobik akan menyebabkan terjadinya penurunan berat badan karena turunnya persentase lemak tubuh. Hasil latihan fisik bukanlah sesuatu yang diperoleh dalam satu atau dua minggu 
latihan. Manfaat latihan fisik baru dapat dirasakan setelah dua sampai tiga bulan lebih latihan. Oleh karena itu, durasi dan program latihan yang teratur dan kontinyu dalam berlatih merupakan syarat yang penting untuk keberhasilan program latihan.

Frekuensi latihan senam aerobik yang dilakukan $\geq 3$ kali dalam seminggu memberikan pengaruh yang signifikan terhadap penurunan persentase lemak tubuh dan berat badan. Hal itu dikarenakan metabolisme lemak bekerja dengan baik. Apabila frekuensi latihan dilakukan tiga kali dalam seminggu, waktu istirahat satu hari dan keesokan harinya sudah melakukan latihan, berarti lemak yang tersimpan dalam tubuh tidak terlalu menumpuk dan tidak akan menjadi timbunan lemak di dalam tubuh, karena lemak tersebut akan segera diproses melalui pembakaran lemak pada saat latihan.

Latihan menyebabkan proses adaptasi pada organ tubuh. Bila frekuensi latihan dilakukan 3-5 kali dalam seminggu, itu artinya organ tubuh akan lebih sering menerima rangsangan ataupun beban dari latihan sehingga proses adaptasi akan berpengaruh lebih cepat. Hal tersebut dikarenakan, disaat latihan maka akan terjadi proses adaptasi pada tubuh. Apabila frekuensi latihan ditingkatkan, maka organ tubuh akan beradaptasi terhadap perubahan tersebut dengan baik. Tetapi tubuh membutuhkan waktu untuk istirahat agar tubuh dapat mengadaptasi seluruh beban selama proses latihan.

Sebaliknya, frekuensi latihan senam aerobik yang dilakukan $\leq 2$ kali dalam seminggu tidak memberikan pengaruh yang signifikan terhadap penurunan persentase lemak tubuh dan berat badan. Hal tersebut dikarenakan, dengan jarak latihan yang lama dan penambahan jumlah lemak yang didapatkan dari asupan makanan selama berhari-hari akan menyebabkan lemak tertimbun dengan banyak dan lama, tanpa ada pengurangan lemak dengan proses pembakaran. Ketika latihan kembali, maka tubuh akan memetabolisme lemak dengan kapasitas tertentu dan tidak bisa membakar semua lemak yang sudah tertimbun. Pembakaran lemak yang terjadi tidak memberikan pengaruh yang signifikan terhadap penurunan persentase lemak tubuh dan berat badan.

Frekuensi latihan senam aerobik yang hanya dilakukan 1-2 kali seminggu hasilnya tidak signifikan. Hal itu disebabkan karena setiap hari tingkat perubahan dari proses adaptasi yang terjadi sangat sedikit dan sulit untuk diukur, sehingga diperlukan latihan yang rutin dan kontinyu agar perubahan pada jaringan di dalam tubuh akan meningkat dan stabil. Latihan yang dilakukan 1-2 kali dalam seminggu tidak akan mendapatkan perubahan yang signifikan, karena waktu latihan yang dilakukan lebih sedikit daripada waktu untuk istirahat, sehingga proses adaptasi yang terjadi merupakan hasil dari latihan akan menurun. Sebaliknya, latihan 
yang dilakukan setiap hari tidak baik untuk kesehatan dan tidak dianjurkan. Tubuh memerlukan jangka waktu tertentu (waktu istirahat) agar tubuh dapat mengadaptasi seluruh beban selama proses latihan (Sukadiyanto, 2011: 18). Latihan menyebabkan kondisi kembali pulih paling sedikit 24jam dalam seminggu, paling banyak 48jam dalam seminggu.

Penurunan persentase lemak tubuh dan berat badan yang tertinggi dalam penelitian ini merupakan member yang melakukan latihan senam aerobik $\geq 3$ kali dalam seminggu, berusia 20-30 tahun dan berprofesi sebagai mahasiswa dan PNS. Hal ini membuktikan bahwa faktor di luar frekuensi latihan senam aerobik juga dapat berpengaruh terhadap keberhasilan penurunan persentase lemak tubuh dan berat badan. Member yang berusia antara 20-30 tahun memiliki proses metabolisme lemak dan daya tahan aerobik yang baik, sehingga dalam proses penurunan akan menjadi lebih optimal. Member dengan profesi mahasiswa dan PNS adalah member yang aktif dalam bekerja dan bergerak, sehingga untuk terjadinya penimbunan lemak ataupun menurunnya daya tahan aerobik berkurang.

Menurut Brian J. Sharkey (2003: 70), senam aerobik sangat efektif bagi wanita yang ingin menurunkan berat badan apabila dilaksanakan secara rutin dan kontinyu. Latihan yang teratur dan terprogram dapat membantu penurunan persentase lemak tubuh, terutama latihan yang bersifat aerobik. Telah diketahui bahwa empat hari latihan hasilnya lebih baik daripada tiga hari. Lima hari latihan lebih baik daripada empat hari. Dari penelitian juga terlihat dua hari latihan perminggu tidak efektif untuk menurunkan persentase lemak tubuh dan berat badan. Dengan kata lain, jika hanya melakukan latihan dua hari perminggu, maka hasilnya hanya sedikit lebih baik daripada tidak melakukan latihan. Dengan demikian frekuensi latihan berpengaruh terhadap penurunan persentase lemak tubuh dan berat badan. Frekuensi yang ideal untuk melakukan latihan senam aerobik adalah 3-5 kali dalam seminggu. Apabila ingin latihan >5 kali dalam seminggu, usahakan agar dapat beristirahat paling sedikit satu hari setiap minggu untuk mencegah terjadinya cedera karena latihan yang berlebih.

\section{KESIMPULAN}

Aktivitas fisik adalah cara yang positif untuk mengontrol perubahan persentase lemak tubuh dan berat badan, tanpa mengurangi jaringan tanpa lemak. Aktivitas fisik seperti senam aerobik tampak lambat dalam menunjukkan perubahan persentase lemak tubuh dan berat badan, namun bila dilakukan secara intensif akan menunjukkan hasil yang cukup baik dalam hal penurunan persentase lemak tubuh dan berat badan. Perubahan persentase lemak tubuh dan berat badan tersebut terjadi karena dengan melakukan olahraga aerobik maka terjadi peningkatan metabolisme tubuh dan itu baik untuk menurunkan persentase lemak tubuh dan 
berat badan yang berlebih. Hal inilah yang banyak diharapkan orang dari olahraga yaitu untuk memperoleh badan yang ideal.

Pelatihan fisik secara aerobik menggunakan lemak sebagai sumber energi dan pelatihan aerobik merupakan metode ideal untuk mengurangi masa jaringan lemak dan menurunkan berat badan. Dengan demikian, melakukan senam aerobik selama 60 menit dalam 3 kali seminggu selama 8 minggu dapat menurunkan $2,05 \mathrm{~kg}$ berat badan. Hasil uji statistik menunjukkan ada perbedaan perubahan persentase lemak tubuh antara sampel yang memiliki frekuensi latihan tinggi dengan frekuensi latihan rendah. Dengan demikian ada perbedaan perubahan persentase lemak tubuh dan berat badan berdasarkan frekuensi senam aerobik. Latihan aerobik 3-5 kali seminggu dapat membantu menurunkan persentase lemak dan berat badan, selain itu juga dapat mempertahankan berat badan yang sudah tercapai.

\section{DAFTAR PUSTAKA}

Aine McCarthy. (1995). Kiat Ramping Dan Tetap Bugar Petunjuk Praktis untuk Hidup Lebih Sehat. Jakarta: PT Gramedia Pustaka Utama.

Brian J. Sharkey (2003). Kebugaran dan Kesehatan. Jakarta: PT Raja Grafindo Persada.

Djoko Pekik Irianto. (2000). "Panduan Latihan Kebugaran”. Yogyakarta: Lukman Offset.

(2006). "Panduan Gizi Lengkap Keluarga dan Olahragawan". Yogyakarta: C.V Andi Offset.

Fajar Sriwahyuniati. (2009). Laporan Kegiatan PPM: Pelatihan Senam Aerobik Produk FIK UNY untuk Instruktur Senam FOMI Kota Yogyakarta. Yogyakarta: FIK UNY.

Fox, E.L. (1984)). Human Physiology. $4^{\text {th }}$ ed. Lowa Wm. Brown Publisher Company.

Suharjana. (2013). Kebugaran Jasmani. Yogyakarta: Jogja Global Media.

Sukadiyanto. (2011). Pengantar Teori dan Metodologi Melatih Fisik. Bandung: CV Lubuk Agung.

Trulyana Tantiani. (2008). "Pengaruh Makan Menyimpang Pada Remaja”. Jurnal Kesehatan Masyarakat Nasional (Volume 2, Nomor 6, Juni 2008).

WHO. (2010). “Obesity”. World Health Organization Technical Repot. Diakses dari http://www.euro.who.int/document/E88086.odf.pa. pada tanggal 17 April 2016.

Widiyanto. (2004). Pengaruh Latihan Fisik Terhadap Penurunan Persentase Lemak Tubuh dan Berat Badan di Vicotory Fit and Fresh Gym Yogyakarta. Skripsi. FIK UNY. 
